\title{
SASKATCHEWAN RESULTS OF THE 1996 INTERNATIONAL PIPING PLOVER CENSUS
}

MARGARET A. SKEEL, DAVID C. DUNCAN, Saskatchewan Wetland

Conservation Corporation, 202 - 2050 Cornwall Street, Regina, SK S4P 2K5 and EARL R. WILTSE, Saskatchewan Environment and Resource Management, 3211 Albert Street, Regina, SK S4S 5W6

The Piping Plover and its endangered status has become familiar to many of us in recent years. This small shorebird first captured the public's attention in 1991 with the occurrence of the first comprehensive international Piping Plover breeding census. In the spring of 1996, attention from researchers and naturalists across Canada and the United States was again focused on this species for the second coordinated complete census of Piping Plover breeding habitat. All nine provinces and 28 states where Piping Plovers are known to breed participated. The goal of the second census was to obtain a reliable estimate of the population in 1996, and to compare this with the 1991 estimate. In Saskatchewan, the 1996 census was coordinated by the authors.

The Piping Plover is very specific in its choice of nesting habitat. It chooses sandy or gravelly beaches along shores of rivers and saline or freshwater lakes and ponds across the Prairies and Great Plains of North America. It also occurs along beaches of the Atlantic coast, where just under half the continental population nests, and in the Great Lakes region, where a remnant population has almost disappeared. Evidence that the Piping Plover may have been in decline prior to $1980,{ }^{1,2}$ coupled with indications from surveys of






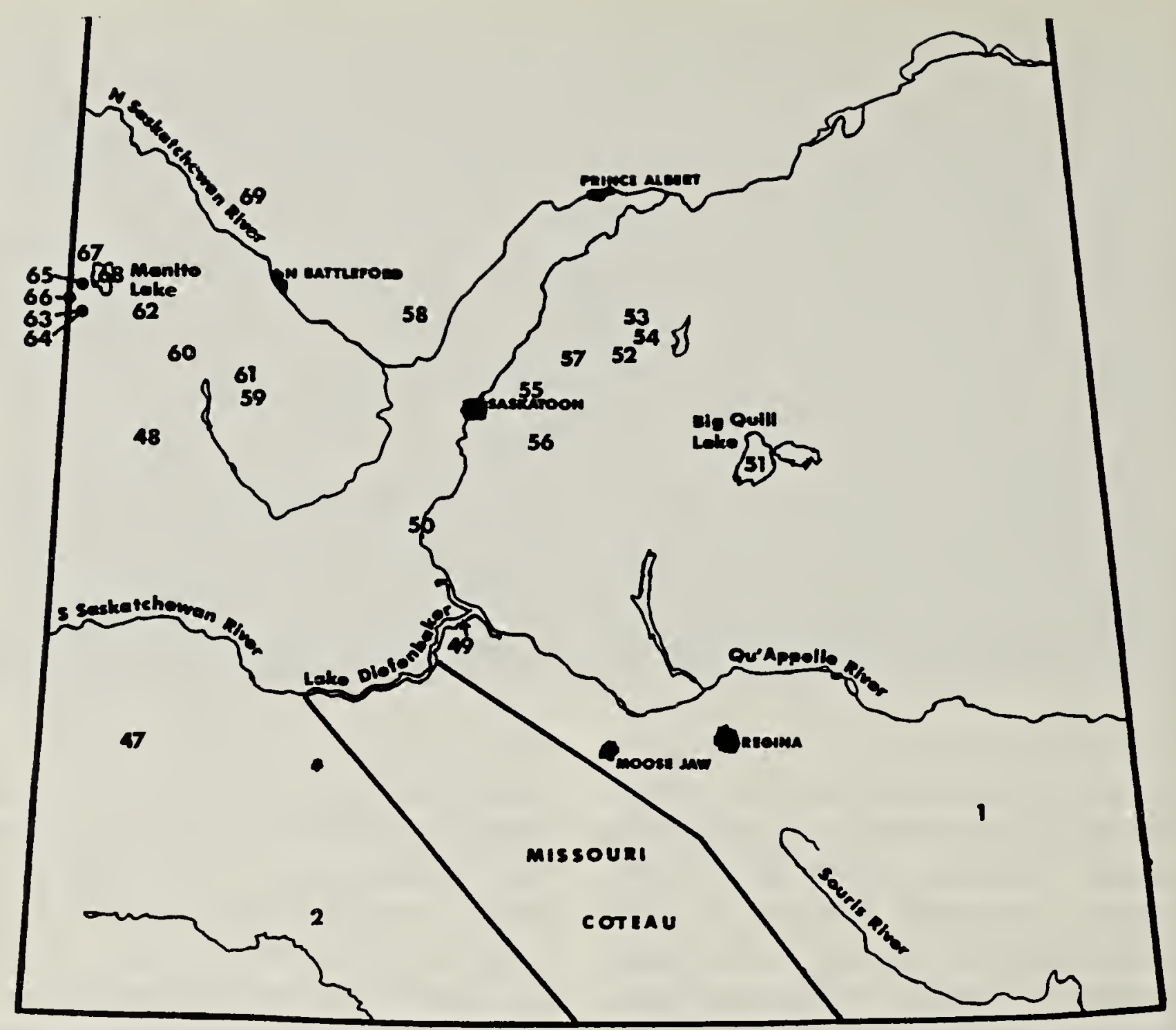

Figure 1. Piping Plover locations in Saskatchewan, 1996, excluding the Missouri Coteau. Numbering follows Table 1.

further decline through the 1980s, were cause for concern and resulted in the Piping Plover being designated as "Endangered" by the Committee on the Status of Endangered Wildlife in Canada (COSEWIC) in 1985. Drought conditions in the 1980 s on the Prairies, and increasing human disturbance, particularly on the Atlantic coast, may have contributed to any recent decline.

In the intervening years since the 1991 census, many regions have acted to improve nesting conditions for the Piping Plover. Actions have included public and landowner awareness of the plover and its habits, fencing of high-use shoreline habitat from cattle on the Prairies, and beach signage and timely closure of some nesting areas to public access on the Atlantic coast.
In 1991, three large basins Lake Diefenbaker, Big Quill Lake and Manito Lake - and a variety of smaller wetlands in the Missouri Coteau area were home to most of Saskatchewan's plovers. $^{19,20}$ Although surveys since 1991 indicated that most of these areas have had consistent plover use, ${ }^{21}$ concentrations of plovers can change dramatically in response to fluctuating water regimes and resulting changes in habitat conditions and availability.

Selection and Surveying of Sites Sites were selected for the 1996 census based primarily on the results of the 1991 census. They included sites with Piping Plovers in 1991, sites with no plovers but identified as having potential habitat, and three sites not visited in 1991 but 


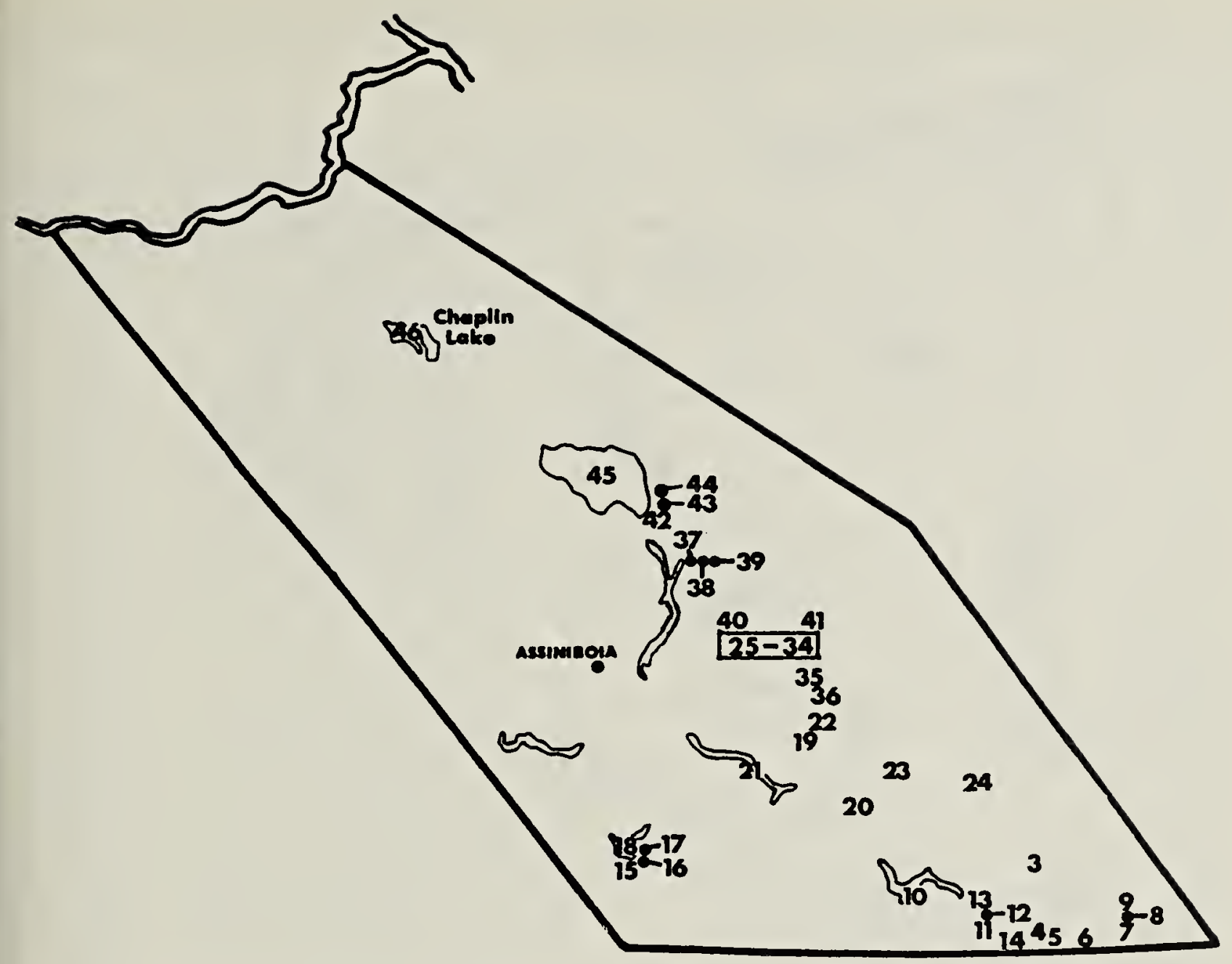

Figure 2. Piping Plover locations in the Missouri Coteau of Saskatchewan, 1996. Numbering follows Table 1.

identified since then as having plovers. For the Missouri Coteau area of south-central Saskatchewan (an area with hundreds of basins), in addition to sites with plovers in 1991, suitable basins identified on an aerial survey (16-20 May 1996) were censused, as was done in 1991. Lake Athabasca, which had no plovers in 1991, was not censused in 1996.

A total of 276 sites were censused, varying in size from a few hectares to thousands of hectares. This was substantially less than the almost 500 sites censused in 1991 because many sites that were of unknown potential in 1991 were eliminated on the basis of having no potential habitat. Participants in the census included biologists from Saskatchewan Environment and Resource Management, Saskatchewan Wetland Conservation Corporation, Canadian Wildlife Service, Ducks Unlimited, consulting biologists on contract, and over 50 volunteers.

All censuses were conducted on 31 May-29 June, with the great majority in the period 1-16 June. Censuses followed procedures set out in the Guidelines for the 1996 International Piping Plover Breeding Census. ${ }^{21}$ Potential threats to the habitat were also identified.

For each site surveyors mapped all observations of breeding pairs, single adults with a nest or young, and unpaired adults. Number of adults recorded was defined as the actual number of individual birds observed. Number of pairs recorded was defined as the number of territorial pairs (presumed mated) plus single adults with a nest or young. (See ${ }^{21}$ for further details of methodology.) 


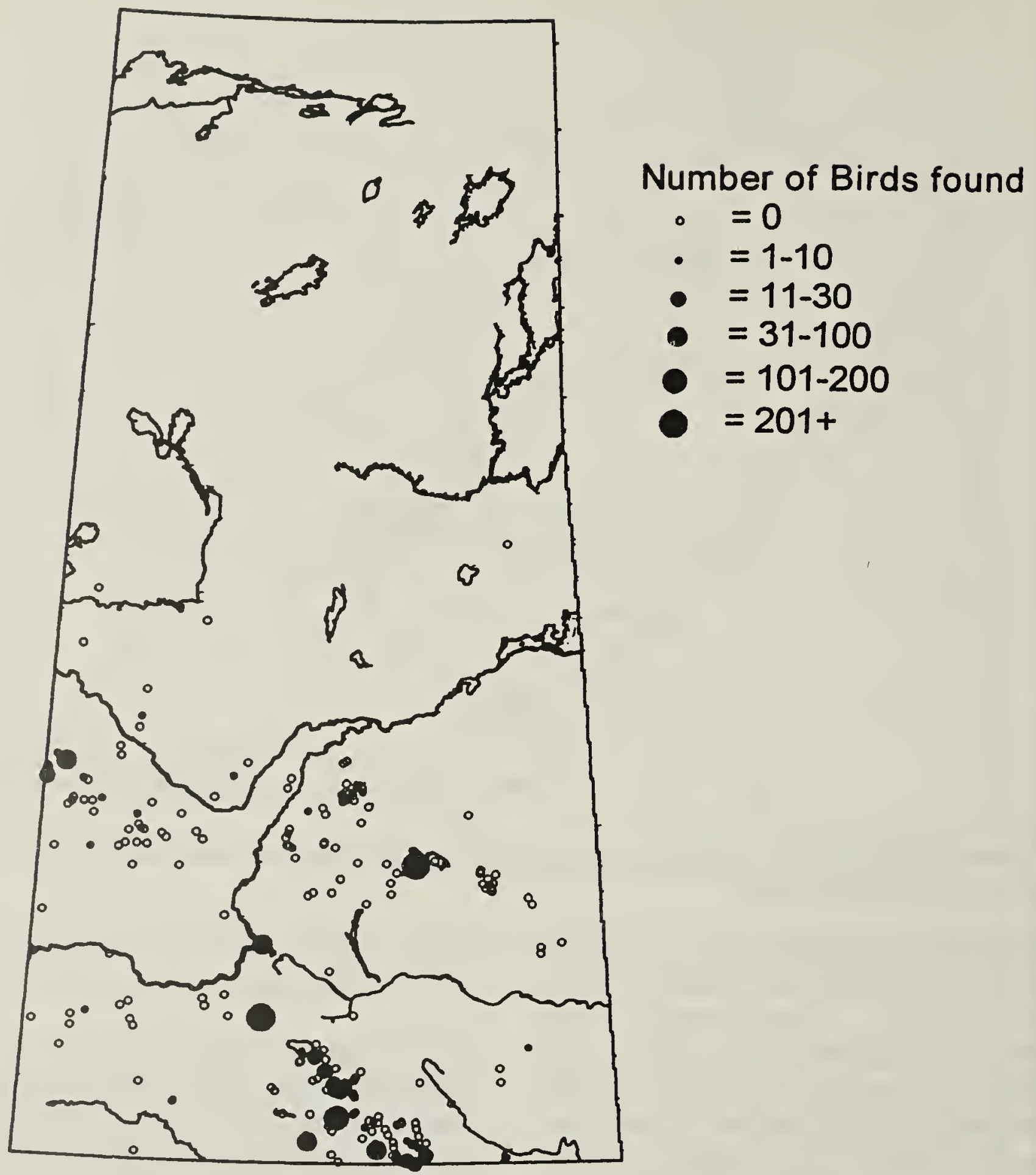

Figure 3. The distribution pattern of Piping Plovers and areas censused for Piping Plovers in Saskatchewan, 1996.

Population Size A high proportion of the world population of Piping Plovers again resided in Saskatchewan. The provincial count of 1348 adult birds comprises $22.9 \%$ of the total North American count of 5896 plovers (J. Plissner pers. comm.). This is similar to 1991 when the count of 1172 birds comprised $21.4 \%$ of the total of 5487 birds. ${ }^{5}$ In the five-year period from 1991 to 1996, an encouraging continental increase of $7.5 \%$ occurred.

Piping Plovers were most abundant on the Prairies/Northern Great Plains, where 3,284 plovers were counted $(3,469$ in 1991) compared to 2,568 on the Atlantic coast $(1,979$ in 1991) and 44 on the Great Lakes (39 in 1991). Although Saskatchewan's "population" exhibited an increase of $15.0 \%$ since 1991 (but see below), the overall population on the Prairies/Northern Great Plains declined by $5.3 \%$. On the Atlantic coast there was an impressive increase of $29.7 \%$.

The 1996 and 1991 Saskatchewan results are comparable. The coverage was similar in both years, as 
Table 1. LOCATION AND NUMBER OF PIPING PLOVERS FOUND IN SASKATCHEWAN, 1996

\begin{tabular}{|c|c|c|c|c|c|c|}
\hline Number & Date & Site ${ }^{a}$ & $\begin{array}{l}\text { Number } \\
\text { of birds }\end{array}$ & $\begin{array}{l}\text { Number } \\
\text { of pairs }\end{array}$ & $\begin{array}{c}\text { Km of } \\
\text { habitat }^{\mathrm{b}}\end{array}$ & $\begin{array}{c}\% \text { of } \\
\text { habitat }^{c}\end{array}$ \\
\hline 1 & 15 June & Kipling Marsh (62L2) & 1 & 0 & 0.5 & 50 \\
\hline 2 & 10 June & trail nr Driscoll Lake & 1 & 0 & 0.0 & $\mathrm{NH}$ \\
\hline 3 & 3 June & $415530(72 \mathrm{H} 1)$ & 1 & 0 & 1.0 & 100 \\
\hline 4 & 7 June & East Coteau Lake & 24 & 9 & 9.0 & 100 \\
\hline 5 & 2 June & Little Coteau Lake (72H1) & 2 & 1 & 1.5 & 100 \\
\hline 6 & 13 June & Alkali Lake & 22 & 5 & 9.6 & 100 \\
\hline 7 & 2 June & $613345(72 \mathrm{H} 1)$ & 1 & 1 & 1.5 & 100 \\
\hline 8 & 2 June & $613353(72 \mathrm{H} 1)$ & 1 & 0 & 0.8 & 100 \\
\hline 9 & 5 June & Sandoff Lake & 28 & 6 & 8.0 & 100 \\
\hline 10 & 15 June & Big Muddy Lake & 34 & 14 & 35.0 & 100 \\
\hline 11 & 1 June & $295330(72 \mathrm{H} 2)$ & 5 & 2 & 2.0 & 100 \\
\hline 12 & 1 June & $300342(72 \mathrm{H} 2)$ & 1 & 0 & 0.5 & 100 \\
\hline 13 & 1 June & $300345(72 \mathrm{H} 2)$ & 2 & 1 & 0.5 & 100 \\
\hline 14 & 1 June & Lonetree Lake & 1 & 0 & 3.0 & 100 \\
\hline 15 & 1 June & Grant Lake & 1 & 0 & 3.0 & 100 \\
\hline 16 & 1 June & $395500(72 \mathrm{H} 4)$ & 1 & 0 & 1.0 & 100 \\
\hline 17 & 1 June & $400535(72 \mathrm{H} 4)$ & 1 & 0 & 3.0 & 100 \\
\hline 18 & 8 June & Fife Lake & 53 & 13 & 29.0 & 100 \\
\hline 19 & 2 June & $850814(72 \mathrm{H} 6)$ & 2 & 1 & 1.0 & 100 \\
\hline 20 & 4 June & Coal Mine Lake & 10 & 4 & 8.0 & 100 \\
\hline 21 & 14 June & Willow Bunch Lake & 124 & 57 & 113.4 & 100 \\
\hline 22 & 2 June & Horizon Lake & 9 & 4 & 10.0 & 100 \\
\hline 23 & 3 June & Edna Lake & 3 & 0 & 10.0 & 100 \\
\hline 24 & 3 June & $304706(72 \mathrm{H} 7)$ & 2 & 0 & 2.5 & 100 \\
\hline 25 & 4 June & Dryboro Lake & 7 & 4 & 4.0 & 100 \\
\hline 26 & 4 June & $650075(72 \mathrm{H} 11)$ & 1 & 0 & 0.8 & 100 \\
\hline 27 & 4 June & Burn Lake & 17 & 8 & 9.0 & 100 \\
\hline 28 & 4 June & $705056(72 \mathrm{H} 11)$ & 11 & 5 & 3.0 & 100 \\
\hline 29 & 3 June & $714054(72 \mathrm{H} 11)$ & 2 & 1 & 1.5 & 100 \\
\hline 30 & 3 June & $717067(72 \mathrm{H} 11)$ & 2 & 1 & 1.5 & 100 \\
\hline 31 & 4 June & Shoe Lake & 12 & 6 & 4.0 & 100 \\
\hline 32 & 4 June & $832010(72 \mathrm{H} 11)$ & 2 & 1 & 1.0 & 100 \\
\hline 33 & 4 June & $840020(72 \mathrm{H} 11)$ & 5 & 2 & 3.5 & 100 \\
\hline 34 & 4 June & $842027(72 \mathrm{H} 11)$ & 5 & 2 & 3.0 & 100 \\
\hline 35 & 5 June & $846992(72 \mathrm{H} 11)$ & 3 & 1 & 3.6 & 96 \\
\hline 36 & 5 June & $856984(72 \mathrm{H} 11)$ & 1 & 0 & 1.0 & 100 \\
\hline 37 & 4 June & $540279(72 \mathrm{H} 13)$ & 22 & 8 & 5.0 & 100 \\
\hline 38 & 5 June & $560273(72 \mathrm{H} 13)$ & 4 & 0 & 3.0 & 100 \\
\hline 39 & 5 June & $565273(72 \mathrm{H} 13)$ & 1 & 0 & 1.5 & 100 \\
\hline 40 & 3 June & Bliss Lake & 18 & 6 & 10.0 & 100 \\
\hline 41 & 3 June & $842162(72 \mathrm{H} 14)$ & 3 & 1 & 1.5 & 100 \\
\hline 42 & 8 June & Frederick Lake & 22 & 8 & 14.0 & 100 \\
\hline 43 & 7 June & $500450(7214)$ & 5 & 2 & 3.0 & 100 \\
\hline 44 & 6 June & $503440(7214)$ & 4 & 1 & 3.0 & 100 \\
\hline 45 & 13 June & Old Wives Lake & 8 & 2 & 115.3 & 100 \\
\hline 46 & 5 June & Chaplin Lake & 205 & 74 & 62.4 & 100 \\
\hline 47 & 6 June & Freefight Lake & 4 & 1 & 5.0 & 100 \\
\hline
\end{tabular}




\begin{tabular}{|c|c|c|c|c|c|c|}
\hline \multicolumn{7}{|c|}{ Table 1 , continued } \\
\hline Number & Date & Site ${ }^{a}$ & $\begin{array}{c}\text { Number of } \\
\text { birds }\end{array}$ & $\begin{array}{c}\text { Number of } \\
\text { pairs }\end{array}$ & $\begin{array}{c}\text { Km of } \\
\text { habitat }^{\mathrm{b}}\end{array}$ & $\begin{array}{c}\% \text { of } \\
\text { habitat }^{c}\end{array}$ \\
\hline 48 & 11 June & Zella Lake & 4 & 2 & 3.2 & 100 \\
\hline 49 & 8 June & Lake Diefenbaker & 75 & 28 & 256.0 & 91 \\
\hline 50 & 5 June & mid. South Sask River & 2 & 1 & 160.0 & 100 \\
\hline 51 & 12 June & Big Quill Lake & 435 & 196 & 122.7 & 90 \\
\hline 52 & 4 June & $665130(73 A 6,5)$ & 2 & 1 & 1.0 & 100 \\
\hline 53 & 13 June & Basin Lake & 3 & 2 & 26.0 & 100 \\
\hline 54 & 13 June & Middle Lake & 3 & 2 & 9.5 & 100 \\
\hline 55 & 11 June & Burke Lake & 1 & 0 & 8.0 & 100 \\
\hline 56 & 14 June & 155642 (73B1) & 6 & 3 & 9.0 & 100 \\
\hline 57 & 3 June & Buffer Lake & 6 & 2 & 1.5 & 100 \\
\hline 58 & 10 June & Redberry Lake & 4 & 2 & 22.0 & 100 \\
\hline 59 & 8 June & 722817 (73C1) & 1 & 0 & 6.0 & 99 \\
\hline 60 & 6 June & Killsquaw Lakes & 4 & 2 & 3.0 & 100 \\
\hline 61 & 11 June & Aroma Lake & 2 & 1 & 4.5 & 100 \\
\hline 62 & 6 June & Seagram Lake West & 7 & 2 & 10.1 & 100 \\
\hline 63 & 4 June & Freshwater Lake South & 17 & 8 & 9.4 & 100 \\
\hline 64 & 4 June & Freshwater Lake North & 4 & 2 & 4.8 & 100 \\
\hline 65 & 5 June & Reflex Lake East & 2 & 1 & 3.8 & 100 \\
\hline 66 & 2 June & Reflex Lake West, SK & 7 & 3 & 3.7 & 100 \\
\hline 67 & 2 June & Wells Lake & 1 & 0 & 0.0 & $\mathrm{NH}$ \\
\hline 68 & 4 June & Manito Lake & 63 & 21 & 77.7 & 100 \\
\hline 69 & 18 June & Russell Lake & 5 & 3 & 3.0 & 100 \\
\hline Total & & & 1,348 & 534 & $1,258.3$ & \\
\hline
\end{tabular}

were the areas of suitable habitat searched $(95.8 \%$ in 1996). Only one site not censused in 1991 was subsequently discovered to support plovers and surveyed in 1996, and only one site with plovers in 1991 was missed in 1996. Taking these two sites into consideration, the 1991 adjusted total of 1170 birds (excluding 2 birds at Skyeta Lake in 1991 from 1172 birds) and the 1996 adjusted total of 1333 birds (excluding 15 birds counted at Freshwater Lake in 1995 from 1348 birds) represents a $13.9 \%$ increase.

With 1348 birds, more plovers occurred in Saskatchewan than any other province or state, followed by North Dakota with 1003 plovers and Nebraska with 366 plovers. Saskatchewan's count comprised $63.9 \%$ of the total Canadian population of 2111 plovers $(60.1 \%$ in 1991$)$, and $79.9 \%$ of the Canadian Prairie population of 1687 plovers $(81.6 \%$ in 1991). The remaining 424 plovers counted in Canada occurred on the Atlantic coast.

From a provincial viewpoint, Saskatchewan's increase from 1991 to 1996 appears promising at first. However, an influx of plovers from elsewhere on the Prairies may have been a major factor in this increase. Plover numbers on the Great Plains of the U.S. decreased from 2032 birds in 1991 to 1597 birds in 1996, a decrease largely attributed to high water and flooding of much of the plover's habitat along the Platte and Missouri Rivers in 1996 (J. Plissner pers. comm.). Many birds that may 
have normally nested there may well have continued on to Saskatchewan. Even if a real increase may have occurred in Saskatchewan's "population," it would be overshadowed by the overall decrease in plovers on the Prairies/Northern Great Plains.

Distribution In Saskatchewan, Piping Plovers were located at 69 basins in 1996 (Table 1, Figs. 1 and 2), compared to 71 basins in 1991. One or more pairs were found at 51 sites versus 57 sites in 1991; these sites represent potential breeding locations.

Although Piping Plovers were located over much of the southern third of Saskatchewan, they were concentrated in three areas: Big Quill Lake, Chaplin Lake, and in the south portion of the Missouri Coteau (Fig. $3)$. These three areas had, respectively, 32\% (435 birds), 15\% (205 birds), and $36 \%$ (483 birds over 43 basins) of the provincial population. Smaller clusters occurred in the northwest by Manito Lake, and in the east portion of Lake Diefenbaker.

Thirty-five basins had plovers in both 1991 and $1996 .{ }^{21}$ Change in basin use primarily occurred at smaller basins and/or at basins with smaller populations. Most basins with at least 10 plovers in 1991 or 1996 had plovers in the other year (17 of 23 basins).

Although the areas of concentration in 1996 appear to have consistent use by Piping Plovers, the magnitude of numbers counted at several key locations differed substantially from counts in 1991. The three most highly populated sites in 1996 had impressive increases over the 1991 counts: Big Quill Lake increased by $263 \%$ (from 151 to 435 birds), Chaplin Lake by $45 \%$ (113 to
205 birds), and Willow Bunch Lake by $300 \%$ (31 to 124 birds). In contrast, Lake Diefenbaker, which had the highest count in North America in 1991, decreased by $77 \%$ (from 276 to 75 birds).

Wide fluctuations in numbers from 1991 to 1996 counts occurred at both small and large sites. Because the provincial population change was relatively small (an increase of $15 \%$ ), this suggests that fluctuations at an individual site are more indicative of a movement from one basin to another, than of an overall population change. The substantial changes in distribution underscore the fact that monitoring population levels at selected sites may not provide an accurate indicator of overall population change.

Quill Lakes The largest breeding population of any basin in North America in 1996 occurred at Big Quill Lake, which attracted $7.9 \%$ of the continental population. In 1991, Lake Diefenbaker had the distinction of being the most important site continentally, with $5.1 \%$ of the population.

Large fluctuations in numbers characterize the "population" at Big Quill Lake, which has supported plovers every year since annual counts began in $19844^{8,10,11,12,14,15}$ Since 1990, counts have consistently been over 100 birds: 110 in 1990, ${ }^{11}$ 151 in $1991,{ }^{12} 211$ in $1993,{ }^{8}$ and peaking at over 440 birds in 1995 (W.C. Harris pers. comm.) and 435 in 1996. (Data is not available for 1992 and 1994, W. Harris pers. comm.) With a low count of 43 plovers in $1989,{ }^{14}$ the 1995 and 1996 counts represent a ten-fold increase over a six-year period. Plovers have been documented around the entire shoreline. In 1991 and 1996, highest 
densities occurred along the entire west and east sides with lowest densities at the north tip and along the south shore.

The wide fluctuations in use by plovers may reflect changes in water level and resulting changes in habitat conditions that have occurred over the last 10 years. Water level at this shallow, expansive lake reached a 30 -year low in 1993, recovering with an increase of $1.15 \mathrm{~m}$ by 1995 , and a further $0.1 \mathrm{~m}$ increase in 1996 (Saskatchewan Water Corporation). In 1989, numbers plummeted as distances between traditional nesting beaches and the water line increased to $1-10 \mathrm{~km} .{ }^{14}$ Numbers began increasing in 1990 as previously barren gravel beaches closer to the existing water line acquired vegetative growth and began supporting nesting plovers. ${ }^{11}$ With increasing water levels from 1994 to 1996 due to higher annual precipitation and spring runoff, the average distance on nesting beaches from vegetation to water was reduced to about $1 \mathrm{~km}$ in 1993 and 1994, and to less than $200 \mathrm{~m}$ in $1995^{\circ}$ and 1996. Piping Plover numbers have steadily increased since 1990 as a result of decreasing distances from nesting beaches to water, which are a function of both water level and consequent vegetative changes.

At Little Quill Lake numbers of plovers also fluctuate with the water regime. Numbers have varied from 0 in 1996 with present high water levels to a high of 39 birds in 1993 when there was substantial exposed shoreline (D. Duncan).

Chaplin Lake Chaplin Lake is also an important breeding site to Piping Plovers. It had the second highest count in Saskatchewan in 1996 (205 plovers), and the third highest count in 1991 (113 birds $\left.{ }^{12}\right)$. In a 1984 partial survey, 253 plovers were counted..$^{15}$ In the years 1987, 1988, and 1990 , when water levels were very low to almost dry, numbers of plovers were also low: $57,{ }^{13} 17,{ }^{7}$ and $66^{11}$ birds, respectively. Progressive increases in water levels in 1991 and 1996 were accompanied by increases in plovers.

The shorelines, and subsequently plover use, of the basins of this large, shallow saline lake change substantially with changes in water level. The west basin and Midtskogen Bay have over the years supported plovers around their entire shores. The west basin has consistently had water and a high proportion of the plovers in surveys since 1984. Available habitat around Midtskogen Bay however was reduced in 1991 and eliminated in 1996 by higher water. The east basin has supported varying numbers of plovers over the years. The south basin supported plovers in 1984, but more recently has had little habitat (dry in 1987, vegetated in 1990, and flooded in 1991 and 1996). Parts of Chaplin Lake that have been flooded in recent years will likely support plovers when the water recedes. Flooding and high water appear to reduce vegetative encroachment and thus renew plover habitat.

\section{Missouri Coteau (excluding} Chaplin Lake) The Missouri Coteau, with its hundreds of basins of varying size, is another area of great importance to Piping Plovers. In 1996, 483 plovers were counted scattered over 43 basins (30 basins with at least one pair). In 1991, 345 plovers were counted over 39 basins (28 basins with at least one pair). ${ }^{20}$ Including the 205 plovers at Chaplin Lake, the total count in 1996 of 688 birds throughout the Missouri Coteau comprises 
$51 \%$ of the Saskatchewan population (in 1991 the total of 458 comprised $39 \%)$.

Although some larger basins with gravelly shores have consistent use, plover use of most basins changes from year to year in response to precipitation and vegetative growth. Of the 59 basins that were used in at least one year of 1991 and 1996, only 21 basins $(36 \%)$ were used in both years. In 1991, when water levels were just beginning to rise after the drought of the late 1980s, there were more basins identified as having habitat (131 basins ${ }^{19}$ ) than in 1996 (93 basins) when water levels were considerably higher and many basins were flooded.

The fewer basins with suitable habitat in 1996 may account for the greater concentration of plovers that occurred at a few of the larger basins, most notably Chaplin (see above), Willow Bunch, and Fife Lakes. Willow Bunch Lake, a long, narrow lake with rocky and gravelly beaches rimmed by high steep banks, had an unexpectedly high count of 124 birds. Birds were distributed along the entire length of the lake, excluding the ends. Two previous counts resulted in only 31 birds in $1991,{ }^{20}$ and seven birds in a 1984 census of $47 \%$ of the shore. ${ }^{15}$ Fife Lake also had an unexpectedly high count of 53 birds, most distributed along the north and east rocky and gravelly shores of this large, wide lake. Previous counts vary from seven birds in 1986 (W. Harris pers. comm.) to 29 birds in $1991{ }^{20}$

Counts of over 20 birds occurred at six other basins of varying size and history of previous use. The plover count of 34 birds at Big Muddy Lake in 1996 was similar to the 1991 count of 26 birds. $^{20}$ Plover habitat at this long, narrow lake is largely restricted to points along the eastern two-thirds. Although Sandoff Lake, a small alkali basin, had counts of 25 and 28 birds in $1991^{20}$ and 1996, respectively, numbers were lower in the intervening years at eight birds in 1993 (D. Hjertaas pers. comm.) and 10 in 1994 (D. Duncan). East Coteau Lake, a midsized basin, has consistently had 2025 birds in 1991 and 1993-1996 (D. Duncan). Alkali Lake (the Canadian portion of this basin's convoluted shoreline) had a high count of 22 birds in 1996, but no birds in $1991^{19}$ and just three in 1994 (D. Duncan). A small unnamed basin (UTM 540 279) with wide gravelly beaches near the northeast arm of Lake of the Rivers supported $>10$ plovers in both census years $\left(11\right.$ in $1991^{20}$ and 22 in 1996), as did Frederick Lake (12 in $1991^{20}$ and 22 in 1996).

A sharp drop in plover numbers occurred at Old Wives Lake since 1991 when 42 birds $^{20}$ were counted. In 1993 and 1994, 12 (D. Hjertaas pers. comm.) and 27 birds (D. Duncan) were counted, respectively, in partial shoreline surveys. Only eight were counted in 1996, most in small gravel areas near seepages along the south or southeast shore. Water levels have become progressively higher since 1991, although the basin remained below historical high levels up to 1996. Several other basins experienced dramatic drops in plover numbers from 1991 to 1996, most notably Channel Lake (from 19 to 0 birds).

Trampling of beaches by cattle was identified as a moderate to high threat to plover habitat at only 10 sites with plovers, including two sites with 10 plovers (Big Muddy and Burn Lakes). ${ }^{21}$ It was considered a low threat at a further 17 sites. Since 
1991, when 21 sites were identified as being threatened to varying degrees from cattle trampling, ${ }^{19}$ fences have been erected on portions of Old Wives, East Coteau, Channel and Edna Lakes (as well as at Big Quill Lake). Drought, a natural cause of reduced habitat availability in 1991, was not a consideration in 1996. Rather, high water contributed to less habitat being available in 1996.

Lake Diefenbaker The plover population at Lake Diefenbaker has been in decline since the 1991 high count of 276 birds $^{20}$ when the highest concentration of plovers in North America occurred here. In 1996, only 75 plovers were counted. The majority of plovers consistently occur in the eastern third of the lake (east of Riverhurst Ferry); west of there suitable habitat occurs only at a few small areas (12 birds at 8 spots in 1991; 4 birds at 3 spots in 1996).

\section{Counts of plovers east of} Riverhurst Ferry yielded 264 plovers in $1991,{ }^{12,19} 140$ in $1992,{ }^{23}$ and estimates of 167 in $1993^{22}$ (78 counted at 5 sites $\left.{ }^{4}\right), 96$ in $1994^{22}$ (83 counted in a nearly complete census; D. Hjertaas pers. comm.), and 120 in $1995^{22}$ (102 counted in a partial census ${ }^{17}$ ), and a count of 71 in $1996 .{ }^{21}$ Of four censuses previous to 1991, a high population occurred only in 1984 with an estimate of 360 plovers $^{22}$ (217 counted over censused sections $\left.{ }^{15}\right)$. Counts yielded 97 plovers in $1988,{ }^{6}$ an estimate of 135 in $1989^{22}$ (94 counted in the Thomson and McKenzie $\mathrm{Arms}^{14}$ ), and an estimate of 61 in $1990^{22}$ (33 counted in the Arms $^{11}$ ).

The number of plovers that nest at Lake Diefenbaker appears to be related to the water level in the reservoir in mid-May when birds are arriving. ${ }^{22}$ The water level on May
12 , the mean initiation date of nests from 1991-1996, was lower in 1984 and 1991, the two years of highest plover counts, than in any other year of counts $(550.6 \mathrm{~m}$ in 1984 and $550.0 \mathrm{~m}$ in 1991 vs. $550.8-554.0 \mathrm{~m}$ above sea level [asl] in the other years; Sask Water Corp.). Lower water appears to result in wider beaches which are more attractive for nesting.

Fledging success appears to be related to water level and change in water level during the breeding period. ${ }^{22}$ The lower the water level on July 1 and the smaller the change in water level from May 12-July 1, the higher the productivity. In 10 years of data from 1986-1996, fledging success varied from 0 or near 0 young/pair (in five of the years) to an estimated 1.48 young/pair. Complete or near complete reproductive failure occurred when the July 1 water level was $556 \mathrm{~m}$ asl (beaches are eliminated at about $556.5 \mathrm{~m}$ ), and when the change in water level from May 12-July 1 was $3.1 \mathrm{~m}$. The data suggests that avoiding both of these conditions would greatly improve productivity of plovers at Lake Diefenbaker.

A rapid rise in water level and elimination of beaches during the breeding period remains the primary threat to Piping Plovers at Lake Diefenbaker in many years. $4,11,12,14,16,17,18$ Predation and human disturbance also have an impact on losses, ${ }^{3}$ although they are relatively minor. The lake may be of particular importance to plovers during periods of drought when other basins may have reduced habitat due to drying or low water.

Acknowledgements This project was made possible through the financial support of Gas Technology 
Canada, the Endangered Species Recovery Fund (funded by the World Wildife Fund [Canada] and Environment Canada), the Saskatchewan Heritage Foundation, Saskatchewan Power Corporation, Saskatchewan Environment and Resource Management (SERM), the Canadian Wildlife Service (CWS), the Elsa Wild Animal Appeal, and the Saskatchewan Water Corporation. The Saskatchewan Wetland Conservation Corporation (SWCC), SERM, and the CWS contributed invaluable logistical and personnel support. We thank $M$. Hlady and L. Groskorth for identifying habitat on the aerial survey and F. Beek for the distribution map.

We thank the many people who conducted the census work, including the biologists and conservation officers from SERM (Wildlife Branch, Parks and Facilities Branch, Conservation Data Centre; 30 people), SWCC (8 people), CWS (7 people), Ducks Unlimited ( 3 people), the contract biologists ( 7 people), and the more than 60 volunteers.

Participants (116 people) in the census were: Bill Aitken, Norma Allen, Mick Bakke, Michael Banks, Leo Belanger, Ray Belanger, Gerry Beyersbergen, John Bond, Evelyn Boon, Doug Bradford, Ed Brockmeyer, Gord Burrows, Kevin Cantelon, Muriel Carlson, Randy Carlson, Warner Carlson, Ben Cruise, Stephen Davis, Dwight Dobson, David Donald, Susanna Donald, Teslin Donald, Rick Douslin, Barry Dowse, Ed Driver, Marg Driver, David Duncan, Richard Elsom, Marcel Ferland, Kim Finley, Kevin Fitzsimmonds, Dean Francis, Burt Gibson, Lois Gibson, Mike Gollop, Stuart Golly, Paul Goossen, Laura Groskorth, Al Gurnsey, Joyce Gurnsey, Andrew Hak, Anne Harris, Valeri Harris, Wayne Harris, Brian
Hepworth, Merv Hey, Dale Hjertaas, Elinor Hjertaas, Paule Hjertaas, Warren Hjertaas, Phyllis Ilsley, Jeff Keith, Jack Kinnear, Shonna Kinvig, Dora Knutson, Wally Kost, Rob Kraft, Dorine Kreuger, Walter Kreuger, Kay Kruger, Mike Kryzanowski, Sheila Lamont, Phil Layh, Ella Leiter, Rudy Leiter, Ray Longmuir, Robert Luterbach, Natasha Lynn, Bruce Martin, Susan McAdam, Don McKinnon, Joyce Monro, Gordon Neish, Laure Neish, Juanita Nerada, Kelly Neuert, Robert Neufeld, Menno Nickel, Chris Penner, Jeanette Pepper, Stephen Pooler, Nick Postey, Karen Pretzer, Pat Rakowski, Kevin Redden, Dorothy Rhead, Ramsey Ross, Pauline Runstedler, Lyle Saigon, Lloyd Saul, Dan Sawatzky, Karen Scalise, Adam Schmidt, Arnie Schmidt, Jim Slimmon, Vivian Slimmon, Alan Smith, Gordon Smoliak, Velma Spizawka, Lloyd Stewart, Irene Stinson, Jim Stock, Helen Trefrey, Dan Vetter, Ed Walker, Kirk Wallace, Robert Wapple, Jim Wedgwood, Shirley Wedgwood, Sheila White, Tom White, Eldon Wildeman, Norma Wildeman, Earl Wiltse, Milow Worel, and Kerry Wrishko.

1. BELL, F.H. 1978. Status report on Piping Plover in Canada. National Museums of Canada and the Committee on the Status of Endangered Wildlife in Canada. Unpub. 39 pp.

2. CAIRNS, W.E. and I.A. MCLAREN. 1980. Status of the Piping Plover on the east coast of North America. American Birds 34:206-208.

3. ESPIE, R.H.M., R.M. BRIGHAM and P.C. JAMES. 1992. Breeding ecology of the Piping Plover at Lake Diefenbaker, Saskatchewan. Canadian Wildlife Service, Edmonton. Unpub. $31 \mathrm{pp}$.

4. ESPIE, R.H.M., P.C. JAMES and R.M. BRIGHAM. 1994. The effect of water level fluctuations on Piping Plover (Charadrius melodus) breeding success at Lake Diefenbaker, Saskatchewan. Canadian Wildlife 
Service, Edmonton. Unpub. $31 \mathrm{pp.}$ plus appendix.

5. HAIG, S.M. and J.H. PLISSNER. 1992. The 1991 Intemational Piping Plover Census. U.S. Fish and Wildlife Service, Twin Cities, MN. Unpub. 200 pp.

6. HARRIS, W.C. 1988. Piping Plover survey - 1988: South Saskatchewan River - Lake Diefenbaker segment (Riverhurst Ferry to the Dams). Sask. Natural History Society, Regina. Unpub. 10 pp. plus map.

7. - 1988. Piping Plover census and evaluation of the effects of experimental habitat enhancement at Chaplin Lake, Saskatchewan. Sask. Natural History Society, Regina. Unpub. 6pp. + map.

8. - 1993. Population census of Big Quill Lake, 1993. Prairie Environmental Service, Inc., Raymore, SK. Unpub.

9. - 1995. Piping Plover population evaluation at Big Quill Lake habitat enhancement study area - 1995. Sask. Wetland Conservation Corp., Regina. Unpub. 29 pp.

10. HARRIS, W.C. and S.M. LAMONT. 1985. Big Quill Lake Piping Plover populations - 1985. Potash Corp. of Sask. Unpub. 24 pp.

11. - 1990. Saskatchewan Piping Plover population assessment 1990: Big Quill Lake, Chaplin Lake, Lake Diefenbaker, Redberry Lake and the South Saskatchewan River (Gardiner Dam to Saskatoon). Sask. Environmental Society, Saskatoon. Unpub. 15 pp. plus appendix.

12. - 1991. Saskatchewan Piping Plover population assessment - 1991: Big Quill Lake, Chaplin Lake, Lake Diefenbaker. Redberry Lake and the South Saskatchewan River (Gardiner Dam to Saskatoon). Sask. Environmental Society, Saskatoon. Unpub. 32 pp. plus maps.

13. HARRIS, W.C., S.M. MCADAM and D.A. WEIDL. 1987. Chaplin Lake, Saskatchewan Piping Plover census and habitat evaluation. Sask. Natural History Soc. and Sask. Parks \& Renewable Resources. Unpub. 8 pp.
14. HARRIS, W.C., S.M. LAMONT and A. SEQUIN. 1989. Saskatchewan Piping Plover surveys - 1989: Big Quill Lake, Lake Diefenbaker, and Redberry Lake. Sask. Natural History Society, Regina. Unpub. 18 pp.

15. HARRIS, W.C., G. WAPPLE, R WAPPLE, $K$. DESMET and S.M. LAMONT. 1985. Saskatchewan Piping Plovers - 1984. Sask. Natural History Society and Sask. Parks \& Renewable Resources, Regina. Unpub. 106 pp. plus appendix.

16. HJERTAAS, P. 1996. 1996 Piping Plover follow-up at Lake Diefenbaker. Sask. Wetland Conservation Corp., Regina. Unpub. 8 pp.

17. MCADAM, S.M. 1995. Lake Diefenbaker Piping Plover survey 1995. Sask. Wetland Conservation Corp., Regina. Unpub. 21 pp.

18. ROBINSON, L. and D. HJERTAAS. 1991. The effect of water level management on the Piping Plover at Lake Diefenbaker. Sask. Parks \& Renewable Resources. Unpub. 35 pp.

19. SKEEL, M.A. 1991. The 1991 international Piping Plover breeding census - Saskatchewan. Sask. Natural History Society. Unpub. 69 pp. plus maps.

20. — 1994. The 1991 Piping Plover census in Saskatchewan. Pages 35 42 in S.F. Fleming (ed.), The 1991 Intemational Piping Plover Census in Canada. Canadian Wildife Service Occasional Paper No. 82, Ottawa.

21. SKEEL, M.A., D.C. DUNCAN and E.R. WILTSE. 1996. The 1996 international Piping Plover breeding census - Saskatchewan. Sask. Wetlands Conservation Corp. and Sask. Environment \& Resource Management, Regina. Unpub. 43 pp. plus appendices and maps.

22. SKEEL, M.A. 1997. Population size and productivity of Piping Plovers at Lake Diefenbaker in relation to water levels - 1984 to 1996. Sask. Wetlands Conservation Corp., Regina. Unpub. 20 pp. plus appendices.

23. WAIT, B. 1992. Piping Plover Survey of Lake Diefenbaker - 1992. Sask. Environment \& Resource Management, Regina. Unpub. 7 pp. 